\title{
The Cultural Doings and Undoings of the Sydney Taylor Book Award
}

\author{
Anastasia M. Collins \\ Beatley Library, Simmons University
}

\begin{abstract}
The children's book award is an ideological vehicle that communicates both implicit and explicit values to the wider world. For half a century, the Sydney Taylor Book Award has invoked criteria of literary excellence and authentic portrayals of Jewish experiences and the implicit cultural values that underpin them in its mission to recognize, celebrate, and perpetuate quality Jewish children's literature. The award upholds and subverts cultural ideas of childhood, literary excellence, and Jewish authenticity in order to resist systems of power and dominant cultural narratives that seek to erase or flatten Jewish representation.
\end{abstract}

Keywords: Sydney Taylor Book Award; children's literature; book awards; cultural impact

\section{INTRODUCTION}

In the early twentieth century, the first book awards were established for children's literature, both as a way to celebrate and to bring legitimacy to quality children's books. Since their inception, awards like the Newbery and Caldecott - first awarded in 1922 and 1938, respectivelyhave had massive impact on the literary world and its surrounding culture. A few decades later, awards that specifically recognize identity-based content and representation came on the scene, and the book award that would eventually be named for the illustrious Sydney Taylor was born. For more than fifty years now, the Sydney Taylor Book Award has been presented to outstanding books for children and teens that "authentically portray the Jewish experience" (Association of Jewish Libraries 2018a). The award is open to Jewish and non-Jewish authors and has steadily expanded over the years to include categories for younger, older, and teen readers, honor books for each category, and an accompanying list of notable books for the year.

On the surface, the Sydney Taylor Book Award serves two purposes: to honor and celebrate the most distinguished Jewish books for children and teens; and to signal excellence to parents, teachers, librarians, and of course to young readers who are looking for quality books that feature Jewish experiences. According to Kokkola (2003, 7), "[w]riting for children, as we have long been aware, is particularly susceptible to ideological shaping," and this is no less true of children's literature prizing. To assign cultural value and a moniker of excellence to literature, let alone Jewish children's literature is no ideologically neutral act and in fact, the Sydney Taylor Book Award not only engages but both reinforces and disrupts cultural ideas regarding children's literature, standards of representation, and the diversity of Jewish identity. 


\section{Awards As Cultural Vehicles}

“The prizing apparatus didn't merely help justify excellent children's literature; it helped to create it." (Kidd and Thomas 2017, 4-5)

The recognition of literary excellence and distinctiveness among works of children's literature can have enormous and lasting impact, and that impact has much to do with money. What ostensibly functions as a mechanism for identifying and celebrating creators' accomplishments with regard to their craft also changes the way the books are received by the rest of the world and the place they will have in our cultural consciousness. When a book receives the shiny badge of an award, it often enjoys longer print runs, increased visibility to readers, and more effective handselling by booksellers, while its author and publisher enjoy their new preface of "award-winning" - all of which amounts to more sales, greater longevity, and even "classic" status. Perhaps most significant is the fact that an award-winning book's enhanced marketplace performance increases the likelihood that more books like it will be published. Far from functioning as detached arbiters of quality among books that happen to fit their respective criteria, children's book awards have a direct hand in defining quality on their own terms and seeing to it that more books that uphold that quality are produced.

For all that children's book awards are in the business of promoting excellent children's literature, they are quite reluctant to define their terms. In fact, as Bittner and Superle $(2017,74)$ remind us, "The primary criterion for identifying prize winners in many major awards_- 'excellence'-seems to invite the application of formalist modes of literary criticism." A criterion of excellence supposes a shared cultural understanding of what makes a book excellent and assumes that its qualities are observable in the book's form and content. But as Readings $(1996,24)$ tells us, "excellence is not a fixed standard of judgment but a qualifier whose meaning is fixed in relation to something else," leaving what Bittner and Superle $(2017,79)$ call "a stunning amount of room for judges' subjective interpretations of 'quality' and 'appropriateness.' " Of course, where subjective interpretation reigns, so too does personal bias. "Bias" here does not mean favoritism for a book or author but rather the collective socializing influence of an individual's experiences and exposures that naturalize what are in fact calculated, normative ideological assumptions. As Bittner and Superle $(2017,79)$ put it, "seemingly objective formalist descriptions belie how individual literary preferences can be leaving an enormous amount of liberty for personal taste to be masked," and a dominant white, male, cisgender, heterosexual, non-disabled, Christian-centric view is not only amplified and naturalized in the guise of "excellence," but reinforced and replicated in award winners.

\section{(Re)Making Excellence}

In 1965, Nancy Larrick published "The All-White World of Children's Books" as a call to end white supremacy in the children's literature publishing industry. Despite shifts in the landscape of children's publishing through, for example, the work of movements like We Need Diverse Books (https://diversebooks.org), many, if not most, of Larrick's concerns and outrage remain 
as relevant today as they were fifty years ago. Her article, however, did prompt immediate action within the children's literature community, most notably the establishment of identity-based children's book awards, the very first of which was the Sydney Taylor Book Award (Cummins 2017, 89). Established in 1968 and swiftly followed by the Coretta Scott King Book Awards ${ }^{1}$ in 1969 to celebrate the African American experience and then the Stonewall Book Awards ${ }^{2}$ in 1971 to honor the LGBTQAI+ experience, the Sydney Taylor Book Award set a new precedent for merit criteria in which literary excellence must be coupled with well-crafted, authentic representation of a particular identity, culture, and experience.

The Sydney Taylor Book Award also engages directly with its cultural role with its mission statement:

[...] to encourage the publication of outstanding books of Jewish content for children and teens, books that exemplify the highest literary standards while authentically portraying Jewish experience. We hope that official recognition of such books will inspire authors, encourage publishers, inform parents and teachers, and intrigue young readers. We also hope that by educating readers about the Jewish experience, we can engender pride in Jewish readers while building bridges to readers of other backgrounds. (Association of Jewish Libraries 2018b)

The award makes no secret of an agenda to qualify excellence, if not in terms of Jewish representation, then in conjunction with it, and here we have a whole new set of implicit assumptions, most importantly that Jewish representation in children's literature is valuable. The award was renamed from the Shirley Kravitz Children's Book Award to the Sydney Taylor Book Award in the year of Taylor's death in honor of her lasting contribution of exactly the kind of affirming Jewish children's literature the award seeks to recognize and promote (Association of Jewish Libraries 2018b). With the All-Of-A-Kind series, Taylor shared the antics and traditions of a quintet of Jewish sisters with non-Jewish readers, but also validated Jewish readers who could now see themselves reflected in a popular book series.

\section{Criteria Considered}

The Sydney Taylor Book Award has six criteria for evaluating books and judging eligibility for

\footnotetext{
1 "The Coretta Scott King Book Awards, established by the Ethnic \& Multicultural Information Exchange Round Table (EMIERT) of the American Library Association, "are given annually to outstanding African American authors and illustrators of books for children and young adults that demonstrate an appreciation of African American culture and universal human values. The award commemorates the life and work of Dr. Martin Luther King, Jr., and honors his wife, Mrs. Coretta Scott King, for her courage and determination to continue the work for peace and world brotherhood." See more information at http://www.ala.org/rt/emiert/cskbookawards.

${ }^{2}$ The Stonewall Book Awards are sponsored by the American Library Association's Gay, Lesbian, Bisexual, and Transgender Round Table. See more information at http://www.ala.org/rt/glbtrt/award/stonewall.
} 
the award: accuracy, age appropriateness, authenticity, depth of Jewish content, positive focus and values, and sensitivity. The last three criteria are fairly straightforward: If we accept the premise that Jewish content in children's books has value (which the author most certainly hopes we do), then it follows that such content should have depth and development and be both affirming and sensitive to the culture it is representing for it to merit an award. It is the first three criteria - accuracy, age appropriateness, and authenticity - that require unpacking to shine light on some of the implicit assumptions at work. These are not necessarily problematic assumptions, but in deference to due diligence, any analysis of the cultural impact of a book award must include both the ideologies it upholds as well as those it subverts.

Pinchuck $(2008,30)$ posits that "literary merit, age appropriateness, authenticity, and accuracy are relatively easy to judge," and that it is Jewish content that is more difficult to assess. But as discussed above, literary merit or excellence as a criterion assumes an objective, know-itwhen-you-see-it standard while in reality there are subjective, culturally-influenced preferences at work. Similarly, accuracy, age appropriateness, and authenticity assume certain ideological stances and reinforce certain cultural understandings of childhood and of children's literature, as demonstrated below. Banks et al. (2006) explore the issue of assessing excellence with regard to the Sydney Taylor Book Award criteria, creating a sort of guide for reviewers. Their expansion on each of the criteria reveals some of the implicit assumptions in play. To be clear, it is not the author's intention to challenge the relevance or efficacy of award criteria like accuracy, age appropriateness, and authenticity as award criteria, but rather to take a critical look at what these criteria might take for granted about the books and their readers.

\section{Accuracy}

Banks et al. $(2006,70)$ maintains that "the least that can be expected of all children's literature is accuracy in dates, spelling, the identification of objects, and empirically verifiable facts." Not only does this assertion reinforce a particular function and therefore responsibility of all children's literature, but it also seems to make a default assumption that a book is either nonfiction or realistic fiction, in which accuracy can actually be assessed. Furthermore, even within realism, accuracy does not necessarily map to affirming representation. As Cole (1994, 83-84) demonstrates in her exploration of gender and gender role representation in Jewish children's literature, some Jewish religious content and cultural values relating to gender as they are accurately portrayed in children's books can be at odds with the lives and gendered experiences of actual Jews. Kokkola $(2003,170)$ offers a final complication, expressing concern that "literary characterization and historical fact have been conflated and are treated as if they were one and the same thing," and that books are at risk of "being judged not as [works] of fiction, but as a presentation of historical fact."

\section{Age Appropriateness}

Just as assumptions underpin accuracy as a criterion, age appropriateness taps into long-held cultural constructions of childhood that suppose a universal lack of knowledge about certain topics 
or experience of particular emotions on the part of children. This is evident in the general stratification of topics across age categories for the Sydney Taylor Book Award, with the Holocaust being concentrated in the teen readers category and cultural transmission topics like traditions, language, and historical figures concentrated in the younger readers category. Age appropriateness performs the work of not only constructing a cultural idea of childhood that may or may not have a correlation to actual children and their lived experiences, but also supposes and naturalizes children's inability to decide for themselves what they find appropriate. Age appropriateness is always in and on adult terms precisely because it prioritizes adults' comfort regarding what children "should" know and when. But there will always be child readers, especially marginalized child readers, whose knowledge and experiences are incompatible with the cultural notion of childhood innocence and incapacity, and as more books that reflect and validate such readers are making their way onto shelves, age appropriateness becomes a relative judgment rather than one that is rigidly delineated.

\section{AUthenticity}

Finally, we come to authenticity, which can perhaps best be described not as a criterion but as a fuzzy set of essential elements related to cultural validity, characterization, and authority that operates in what Rosenblatt $(1988,4)$ calls the "complex, non-linear, self-correcting transaction between reader and text." Definitions for authenticity or authentic representation of a particular identity or culture have long been debated, and many resist defining it at all, in part because of how context-dependent authenticity seems to be from narrative to narrative and reader to reader. Some common threads that appear in specific reference to authentic Jewish representation include "realistic and respectful" (Banks et al. 2006, 71); "genuine portrayals and avoidance of stereotypes" (Machet 1998, 114); and "accurate cultural details and values and attitudes generally accepted by the culture" $(115)$. Banks et al. $(2006,71)$ also posit that "if Jewish questions underlie a book's theme and if the author attempts to answer them in a Jewish context, then the result is likely to be authentic." While not exactly helpful as a definition, this framework certainly emphasizes the significance of context to authentic representation. The implicit value underlying authenticity (however fuzzily defined) as a criterion is that inauthentic representation is not only identifiable but also incompatible with excellence.

\section{Disrupting the Single Story}

In 2009, Nigerian writer Chimamanda Ngozi Adichie delivered a TED talk entitled "The Danger of a Single Story." In it, she discusses the negative consequences of reducing a person or group of people to a single narrative. She uses Africans as an example, and the single story that supposes an entire continent of people from different countries, cultures, and backgrounds all to be poor, starving, illiterate, and pitiable. Beyond the sheer inaccuracy, Adichie contends that the single story also precludes the possibility of commonality and connection, precisely because the single story is dehumanizing. "The single story creates stereotypes. And the problem with stereotypes is not that they are untrue, but that they are incomplete. They make one story become the only story" (Adichie 2009). 
Children's literature is no stranger to the single story, and as Adichie touches on in her talk, children's literature plays a significant role in creating and perpetuating single stories about marginalized identities and cultures because of three interlocking facts:

"One of the primary conduits for sending [ideological] messages to students is through children's literature" (Tschida, Ryan, and Ticknor 2014, 28);

Children's books may be "the only place where readers may meet people who are not like themselves" (29); and

Children's books featuring marginalized identities or experiences are largely underrepresented (Cooperative Children's Book Center 2019).

Adichie also reminds us that single stories are closely tied to power and how it is distributed among different social groups. "How [stories] are told, who tells them, when they're told, how many stories are told, are really dependent on power. Power is the ability not just to tell the story of another person, but to make it the definitive story of that person" (Adichie 2009). Antisemitism and Christian-centrism in the United States contribute to the erasure of the full vibrancy of Jewish culture as it is portrayed in literature and the media in favor of the culturally-loaded shorthand of stereotypes. While stereotypes abound about Jews and Jewish culture, the most prevalent single story perpetuated in children's books and especially in young adult literature reduces Jewish culture and history to the horrors of the Holocaust. Reinforced in the United States by children's literature itself, along with school curricula, and other popular attention such as films and memorial museums, this single story relegates Jewish people to the past tense and within the spectacle of extreme suffering.

\section{Holocaust Narrative Saturation}

"When children cannot find themselves reflected in the book they read, or when the images they see are distorted, negative, or laughable, they learn a powerful lesson about how they are devalued in the society of which they are a part." (Bishop 1990, x)

Eichler-Levine explores both the prevalence of Holocaust narratives and the conflations of the Holocaust with Hanukkah in Jewish children's books. She focuses on the 1990s through the early 2000s because "this time coincides with a tremendous increase in American interest in the Holocaust. [...] It is thus not surprising that children's books from 1990 to the present reflect a corresponding rise in representations of the Holocaust" (Eichler-Levine 2010, 95-96). While Eichler-Levine is specifically interested in the conflation of the Holocaust and Hanukkah, she theorizes that the pairing is "both a bizarre juxtaposition and a logical reflection of how Jewish identity is represented in American culture" (97, original emphasis). The mechanisms underpinning the ways that Jewish identity is presented to and understood by non-Jews both influence and are influenced by the Sydney Taylor Book Award. 
During the 1990s, the Holocaust received a great deal of attention in school curricula. Referencing Timothy Cole (2000), Eichler-Levine (2010) explains that this trend can be attributed to the

"myth of the Holocaust," which is not meant to suggest that the events of the Holocaust did not happen, but, rather, that the explosion of Holocaust representations and "experiences"...have resulted in... a "virtual Holocaust" that consumers, museum visitors, and other receivers take to heart as the "real" thing. (98)

For non-Jewish students, a young adult Holocaust narrative and a trip to one of the country's sixty or so Holocaust museums and memorials might be their first and only exposure to Jewish history, culture, or representation. And more to the point, "when American children, both Jewish and non-Jewish, read about Jews, chances are, they are reading about the Holocaust" (EichlerLevine 2010, 111).

With this saturation of Holocaust narratives, we risk what Adichie calls a "flattening" of Jewish identity and representation into a single story of those elements of Jewish culture and history already most accessible and assimilable to non-Jews. This single story, reinforced by cultural institutions like public schools, does not represent Jewish people as people; instead, they are reduced to a historical event, a "single story of catastrophe" (Adichie 2009).

\section{Awards and Resistance}

How can a book award resist such a dominating influence especially when at first glance it appears to be part of the problem? Eichler-Levine $(2010,112)$ notes, and a brief look at the list of past winners and honors confirms, that "in some years, books with Holocaust-related content have dominated the Sydney Taylor awards." This is significant not just because of the award's mission to encourage an expansive presence of quality Jewish content but also because of the cyclical relationship between awards and publishers. As awards honor particular books that center the Holocaust, positively affecting their sales and longevity, it becomes in the interest of publishers' bottom lines to produce similar books with similar Holocaust content. Likewise, if similar books are the majority of what is published the following year, the award committee is likely to give the award to a book featuring the Holocaust that year as well. And on it goes.

In a society primed for anti-Semitism, Jewish traditions and experiences are either devalued or valued only insofar as they align with Christianity. (Consider the assumed significance of Hanukkah because of its alignment with Christmas, but lack of awareness about Yom Kippur or Rosh Hashanah.) The simple existence of an award that presumes the value of Jewish representation and that explicitly seeks to encourage the production of good Jewish children's books is already a resistance to stereotyped notions of Jewish experience, but more than this, what appears to be the award's complicity in the creation of a single story of Jewishness vis-à-vis the Holocaust is, in fact, the exact opposite. The proliferation of Holocaust narratives as award winners, honors, 
and notable books actually helps disrupt the reduction of all Jewish culture and history to the Holocaust.

Narratives that span genres and reading levels coupled with award criteria that ensure accuracy and validity refute the notion that there is only one Holocaust story or that the Holocaust as a historical event has no bearing on the present. Even among just the 2018 award winners, honors, and notable books, the Holocaust and the Jewish identities and culture it threatened are approached in myriad ways. The stories connect to readers in the present via different genres and storytelling techniques, from fantasy to realism to time travel. Also among the five decades' worth of Sydney Taylor Book Award winners are "books about the Sabbath and holidays; the Holocaust; Israel; Bible Stories; Jewish folktales and legends; biographies of notable Jews; historical fiction about the immigrant experience, the Spanish Inquisition, and medieval France; and Jewish customs and rituals" (Pinchuck 2008, 30). The juxtaposition of Holocaust narratives with books featuring other topics strikes a necessary balance of life-affirming stories and stories of brutality and violence - that is, stories that demonstrate Jewish humanity and stories that reclaim Jewish humanity.

\section{FINAL THOUGHTS}

For fifty years, the Sydney Taylor Book Award has used the cultural vehicle of the children's literature award to declare implicitly and explicitly that Jewish children's books are valuable and worthy of recognition. With book lists like AJL's "Jewish Valuesfinder" (https://jewishlibraries. org/Jewish_Values Finder) that highlight even more books with Jewish content, and partnerships like that with the PJ Library (https://pjlibrary.org) and its mission to disseminate thousands of free copies of award winners and other chosen books, the Sydney Taylor Book Award promotes the rich diversity of Jewish lives and experiences, traditions, and values to the benefit of Jewish and non-Jewish readers alike. As the Sydney Taylor Book Award moves into its next fifty years of literary and cultural work, we can explore further questions about the award's cultural position and impact: how does the award, its criteria, and its mission implicitly value particular genre conventions or storytelling craft; how does the narrative and cultural function of childhood in the award-winning books from each age category engage with the historical moment of their production; what trends can be identified across different Sydney Taylor committees' working definitions of "excellence" and the books they ultimately awarded? In their exploration of gender representation in Jewish children's books, Sigalow and Fox $(2014,417)$ remind us that "children's books are important indicators and inculcators of cultural norms." Whatever insights future research might provide us, the Sydney Taylor Book Award's legacy has ensured that we can look forward to a children's literature landscape where Jewish children are reflected and validated in a multitude of well-crafted narratives, and the fullness of their worth and dignity is without question. 


\section{SOURCES}

Adichie, Chimamanda Ngozie. 2009. "The Danger of a Single Story.” Filmed July 2009 at TEDGlobal, Oxford, UK. Video, 18:43. Accessed March 1, 2020. https://www.ted.com/talks/ chimamanda adichie the danger_of_a single story?language $=$ en\&utm campaign $=$ tedspread-sharetrade-a\&utm_medium=referral\&utm_source=tedcomshare.

Association of Jewish Libraries. 2018a. "Sydney Taylor Book Award.” Accessed July 13, 2018. https://jewishlibraries.org/Sydney_Taylor_Book_Award.

Association of Jewish Libraries. 2018b. "Sydney Taylor Book Award: About the Award." Accessed July 13, 2018. https://jewishlibraries.org/content.php?page=Sydney_Taylor_Book Award About the Award.

Banks, Cheryl, Ellen G. Cole, Linda R. Silver, and Lisa Silverman. 2006. "The Quest for Excellence in Jewish Children's Literature.” Judaica Librarianship 12: 69-78. https://doi. org/10.14263/2330-2976.1098.

Bishop, Rudine S. 1990. "Mirrors, Windows, and Sliding Glass Doors." Perspectives 6 (3): ix-xi.

Bittner, Robert, and Michelle Superle. 2017. "The Last Bastion of Aesthetics? Formalism and the Rhetoric of Excellence in Children's Literary Awards." In Prizing Children's Literature: The Cultural Politics of Children's Book Awards, edited by Kenneth B. Kidd and Joseph T. Thomas, 73-86. New York: Routledge,

Cole, Ellen G. 1994. “Gender Portrayal in Jewish Children's Literature.” Judaica Librarianship 8: 83-86. https://doi.org/10.14263/2330-2976.1235.

Cole, Timothy. 2000. Selling the Holocaust: From Auschwitz to Schindler, How History Is Bought, Packaged, and Sold. New York: Routledge.

Cooperative Children's Book Center, School of Education, University of Wisconsin-Madison. 2019. "Publishing Statistics on Children's Books about People of Color and First/ Native Nations and by People of Color and First/ Native Nations Authors and Illustrators." Accessed May 15, 2019. https://ccbc.education.wisc.edu/books/pcstats.asp.

Cummins, June. 2017. "The Still Almost All-White World of Children's Literature: Theory, Practice, and Identity-Based Children's Book Awards.” In Prizing Children's Literature: The Cultural Politics of Children's Book Awards, edited by Kenneth B. Kidd and Joseph T. Thomas, 87-103. New York: Routledge.

Eichler-Levine, Jodi. 2010. "The Curious Conflation of Hanukkah and the Holocaust in Jewish Children's Literature.” Shofar 28 (2): 92-115. http://www.jstor.org/stable/10.5703/shofar.28.2.92. 
Kidd, Kenneth B., and Joseph T. Thomas, Jr. 2017. “A Prize-Losing Introduction.” In Prizing Children's Literature: The Cultural Politics of Children's Book Awards, edited by Kenneth B. Kidd and Joseph T. Thomas, 1-18. New York: Routledge.

Kokkola, Lydia. 2003. Representing the Holocaust in Children's Literature. New York: Routledge.

Larrick, Nancy. 1965. “The All-White World of Children's Books." Saturday Review 48 (September): 63-65, 84-85. http://www.unz.com/print/SaturdayRev-1965sep11-00063.

Machet, M. P. 1998. “Authenticity in Holocaust Literature for Children.” South African Journal of Libraries and Information Science 66 (3): 114-121. http://sajlis.journals.ac.za/pub/ article/view/1440.

Pinchuck, Kathe S. 2008. "Recognizing Jewish Children's Literature for Forty Years: The Sydney Taylor Book Award.” Judaica Librarianship 14: 27-34. https://doi.org/10.14263/23302976.1071.

Readings, Bill. 1996. The University in Ruins. Cambridge, MA: Harvard University Press.

Rosenblatt, Louise M. 1988. "Writing and Reading: The Transactional Theory." Center for the Study of Reading Technical Report 416: 1-18. https://www.ideals.illinois.edu/bitstream/ handle/2142/18044/ctrstreadtechrepv01988i00416 opt.pdf? sequence=1\&isAllowed=y.

Sigalow, Emily, and Nicole S. Fox. 2014. "Perpetuating Stereotypes: A Study of Gender, Family, and Religious Life in Jewish Children's Books." Journal for the Scientific Study of Religion 53 (2): 416-431. https://doi.org/10.1111/jssr.12112.

Tschida, Christina M., Caitlin L. Ryan, and Anne Swenson Ticknor. 2014. "Building on Windows and Mirrors: Encouraging the Disruption of 'Single Stories' through Children's Literature." Journal of Children's Literature 40 (1): 28-39. https://www.questia.com/library/ journal/1P3-3341078701/building-on-windows-and-mirrors-encouraging-the-disruption. 